\section{JIBM}

Journal of International Business and Management (JIBM) Journal Homepage: https://rpajournals.com/jibm

\title{
Government Entrepreneurship Programmes and Unemployment in Osun State, Nigeria
}

\author{
Ibitomi Taiwo" \\ Eke Tobias \\ Hammed Akeem \\ Isiaka Abdulakeem Abiodun \\ Achievers University, Owo, Ondo State, Nigeria' \\ Kogi State University, Anyigba, Nigeria \\ University of Ilorin, Nigeria ${ }^{\text {sed }}$
}

\begin{abstract}
Youth unemployment is one of the most difficult problem threatening economic development of many nations. Entrepreneurship Development Programme (EDP) is therefore increasingly recognized all over the world, as a panacea to ameliorate the menace of unemployment. Any country that attaches special importance or gives special attention to entrepreneurship stands a better chance of reducing unemployment and improved economy. This study therefore seeks to examine the impact of EDP on the menace of unemployment in Osun state, Nigeria. The specific objective seeks to examine the impact of National Directorate of Employment (NDE) on youth empowerment; and determine the effect of N-power on poverty reduction in Osun state. The study adopted survey research design, using item structured instrument to elicit information from the respondents, for a true representation of the whole population of twenty-five and seventeen thousand $(25,000$ $\& 17,000)$ from both NDE and N- power respectively. The sample of four hundred (400) and two hundred and fifty (250) from both NDE and N -power respectively, making a total of six hundred and fifty (650) respondents was drawn from the population using Taro Yamane (1967) formula for estimating sample. A total of 650 questionnaires were administered out of which six hundred and thirty-two (632) were properly filled and returned. The formulated hypotheses were tested using multiple regression with the aid of Statistical Package for Social Science (SPS Version-20). The finding of the study revealed that NDE programmes have significant impact on job creation. with the R2 of 0.598 . The study also revealed that $\mathrm{N}$-power significantly address poverty reduction, most especially in Osun State, with R2 value of 0.687, which indicate that technical skills which comprises of cognitive and non-cognitive skill actually reduced unemployment. Therefore, it was recommended that, in other to produce a typical entrepreneur that will not only be selfemployed but employ more other unemployed youth, government should make it as a point of duty that beneficiaries are given practical training and ensure they acquire technical skills, both cognitive and non- cognitive skill during and after the programme. Keywords: Entrepreneurship Development Programme (EDP), Skills, National Directorate of Employment (NDE), N-power, Youth empowerment
\end{abstract}

*Corresponding author: Ibitomi Taiwo; Email: prof4real4all@gmail.com DOI: https://doi.org/10.37227/JIBM-2021-12-3284 


\section{Introduction}

Despite that most developing countries of the world are now understanding the impact of entrepreneurship programmes on unemployment and the growth of their economy, and therefore making deliberate efforts to promote entrepreneurship, maintain and sustaining effective entrepreneurship development programme remains a global phenomenon. The relationship between effective entrepreneurship programme and unemployment is so important that almost all nations of the world takes entrepreneurship as a top priority in their agenda. Entrepreneurship is gaining grounds all over the world, as government at all levels are now taking steps towards promoting its continuation. In spite of this, there is still a persistent increase in the rate of unemployment all over the world, particularly in Africa.

In Nigeria and even in other countries for example in Bangladesh, Entrepreneurship Development Programme is now being considered as important driver of economic growth, generating employment, fostering innovation and poverty reduction through the empowerment of young men and women (Wernerheim, 2010; Islam, Jantan, Hunt, Rahman, \& Abdullah, 2019). Thus, researchers and other scholars have started prescribing entrepreneurship development programmes as the feasible and permanent solution to the extreme hunger and poverty which accompanies unemployment in Nigeria.

An entrepreneur is one who undertakes an enterprise, acting as conciliator between capital and labour in order to produce goods and services. Creativity and innovation are important techniques that help the entrepreneur to see things in a different perspective and initiate new approaches to the business (Aribaba, 2013). The great need for entrepreneurship development in Nigeria today, more than ever, is as a result of the rate of unemployment and its effect on both the people and the nation and the need for small and medium enterprises. Government programs targeted at reducing unemployment have either not leveraged such chances or given up adjusting the interventions because of a lack of motivation to try up new ventures (Agwu, 2019). There are additional possible internal variables that may be responsible for these issues because of these stubborn ways to solving this ever-increasing unemployment.

Unemployment is one of the developmental problems that face every developing economy of the world. This has become a global concern and has more direct consequences on the youth who would have been the next generation of potentially productive economic and a threat to political, socio-economic fortunes as well as peace and stability of many countries also. Despite the fact that Nigeria is Africa most populous country, the dreadful state of unemployment in Nigeria is well known to all Nigerians and the government at all levels, non-Governmental organization and well-meaning Nigerians are now struggling with the strategy to reduce unemployment in Nigeria. Based on this, it is still observed that Unemployment rate in most developing nations including Nigeria is on the increase and threatening (Mathew \& victor, 2018).

One of the steps taken by the Nigerian government to reduce the problem of unemployment in Nigeria was the establishment of the National Directorate of Employment (NDE), which was established in November 22, 1986. The objective of NDE was to promptly and effectively fight unemployment by designing and implementing innovative programmes, which are directed towards the provision of training opportunities to unemployed youth and small scale entrepreneurs. Also, the N-Power program was introduced by President Muhammadu Buhari in 2016, to reduce the increasing rate of youth unemployment in Nigeria. Many still question the effectiveness of the N-Power program to be beneficial to the increasing population of unemployed youths as unemployment rate keep rising on a daily basis in Nigeria. 
Despite various entrepreneurship development programmes by different level of governments in Nigeria, unemployment remains a major challenge to the developmental process of the Nigeria economy. This has informed the need to embark on the present study with a view to assessing and determining the extent to which the National Directorate of Employment (NDE) and N-power programme of the government has proved effective for achieving a reasonable level of employment in Osun State of Nigeria (Ibitomi \& Adeleke, 2020).

Failure of various entrepreneurship programmes to achieve the desired result is attributed to inability of government to develop a strategy for monitoring the Agency saddles with the responsibility of each programme on a regular basis. Some of these headsmen are left uncheck over a reasonable period of time, therefore making corruption, in all its ramifications, continued to be a serious obstacle to the survival of various entrepreneurship development programmes in Nigeria. Okafor, (2019) viewed that corrupt practices appear to permeate all levels of our public life, from high ranking officers, who collect material inducement to disburse government approved funds to micro, small and medium scale enterprises, down to office assistants, who declare files missing if not submitted with tips.

Failure on the part of government to preparing young Nigerians and equipped them with world-class skills and certification that they need to become innovators and movers of domestic and global markets as hindered the effectiveness of Entrepreneurship development programmes. Lack of quality training systems to impact the skill necessary to become the real entrepreneur onto the beneficiaries despite the fact that skills are at the core of improving entrepreneurship to reduce unemployment rate in Nigeria, as it is in many developing countries. leaving beneficiaries ill-prepared to be self-employed or employer of labour or for the labor market.

None of the previous studies dealt with the impact of government entrepreneurship programmes on the menace of unemployment despite the fact that entrepreneurship is considered highly labour intensive and one of the leading overall employment of labour in Nigeria. Therefore, how NDE affects or translate to job creation and how N-power actually reduced poverty in Osun State is yet to be known. Thus, this is considered the gap in the literature that warrant a study to be carried out on the subject matter. Therefore, the study intends to provide an insight into the impact of government entrepreneurship programmes on the menace of unemployment in Osun State, Nigeria. The main objective of this study is to examine the impact of government entrepreneurship programmes on the menace of unemployment. Specific objectives are to:

i. determine the effect of N-power on poverty reduction; and

ii. examine the impact of NDE on youth empowerment

In order to achieve the stated objectives, the following research questions were generated from statement of the problem to address the problems identified;

i. What is the significant impact of $\mathrm{N}$-power on poverty reduction?

ii. To what extent does National Directorate of Employment programmes impact on youth empowerment?

In other to achieve the stated research questions and objectives, the study employed the following research hypotheses:

$\mathrm{Ho}_{1}$ : N-power does not significantly address poverty reduction in Osun State.

$\mathbf{H o}_{2}$ : NDE programmes does not have significant impact on youth empowerment as a result of government commitment.

The scope of the study covered the entire Osun State, the reason for the choice was that, it is one of the most strategic states in the country and the place of the residents of the researchers. 
The variables used for the study were N-Power and NDE, the reason for the choice was due to the fact that it the most important tools used by the federal government in ensuring reductions of unemployment in the country. The time scope used for this study was from 2020 to 2021, the reason was that the study started in year 2020 and ended in 2021.

\section{Literature Review}

\section{Concept of Entrepreneurship Development Programmes}

Adelekan and Tijani (2017) observed that entrepreneurship development is the ability to envision and chart a course for a new business venture by combining information from the functional disciplines and from the external environment in the context of the extraordinary uncertainty and ambiguity which faces a new business venture. A greater percentage of jobs are created by entrepreneurs who started with small businesses (Mathew \& Victor, 2018). It is important to note that entrepreneurship involves the issue of planning, organizing and managing of resources regarding a business stands out clearly as functions of the entrepreneur. Entrepreneurship is the process of understanding activities concerned with identifying and exploiting business opportunities while assuming its attendant risks. Entrepreneurship involves taking chances, because new businesses do not emerge by accidents (Eme, 2015).

Entrepreneurship Development Programmes (EDPs) have been described by Iwayemi (2013) as a purposeful intervention by an adult (the teacher) in the life of a learner to impart entrepreneurial qualities and skills to enable the learner to survive in the world of business. Its aim is to equip learners with skills, knowledge and disposition that can help them develop or implement innovative social entrepreneurial venture or business plans (Haque, Anwar, Yasmin, \& Islam, 2018). Accordingly, Sule (2014) defines EDP as the process of enhancing entrepreneurial skills and knowledge through structured training and institutional building programmes. Entrepreneurship Development Programme in the context of this study refers to the process of enhancing the capacity of recipients through structured training and institutional building programme.

For the purpose of this study, Entrepreneurship Development Programmes is therefore defined as an intervention strategy by people concerned to produce innovators who can create an invention, a new business venture or run an enterprise successfully and seek out investment opportunities, which reduces unemployment and transform economy (Agwu, 2019)

\section{Concept of N-Power}

N-Power is a job creation and empowerment programme of the National Social Investment Programme of the Federal Government of Nigeria. It aspires to provide a platform where most Nigerians can access skills acquisition and development. The N-Power programme has been designed for young Nigerians between the ages of 18 and 35. It is a paid volunteering programme of two-year duration. N-Power The programme is divided into Graduate Category which are: (i). N-Power Teach Volunteers are deployed as teacher to assist in teaching, school management and other functions within the schools. Where possible, they are also required to assist in taking basic education to children in marginalized communities primary and secondary schools in the country. (ii). N-Power Health beneficiaries are required to assist in improving and promoting preventive healthcare in their communities to vulnerable members of the society including pregnant women and children and to families and individuals. This area is reserved for those who read health and medical related courses 
at certificate course and diploma levels. (iii) N-Power Agro beneficiaries are intended to provide advisory services to farmers across the country. They are expected to disseminate the knowledge that has been amassed by the Federal Ministry of Agriculture and Rural (iv) Development in the area of extension services. They are also required to gather data of Nigeria's agriculture assets. This area is meant for youth who were educated in agricultural related courses The Voluntary Asset and Income Declaration Scheme (VAIDS) VAIDS seeks to encourage non-compliant and partially compliant taxpayers to voluntarily declare their correct income and assets and pay the appropriate tax due to the government and act as community tax liaison officers. And Non-Graduate Category comprising of N-Power Knowledge and N-Power Build. (N-Power Information guide, 2017).

\section{Concept of National Directorate of Employee (NDE) Programmes}

The National Directorate of Employment (NDE) was established on the 24th October, 1986 but commenced full operation in January 1987 with the primary aim of promoting skill acquisition, self-employment and labour intensive work scheme. The National Directorate of Employment (NDE): Legally empowered by NDE Act, CAP 250 of the Law of the Federal Republic of Nigeria (formally Decree No 34 of 1989, the Directorate has responsibility to design, and implement programmes to combat mass unemployment in Nigeria. The scheme was targeted at school leavers, apprentices, graduates and many others.

The programme was to address four (4) major areas: Small Scale Enterprises programme; Vocational skill development programme; Rural employment promotion programme; Special public work programme. The aim of the agricultural programme is to generate employment for graduates, non-graduates and school leavers in the Agricultural sector, with emphasis on self-employment in agricultural production and marketing. The programme is monitored by a team of Agricultural professionals in the Agricultural department of the directorate (DFID, 2017).

Other government entrepreneurial development programmes includes, National Technology business incubation Center (NTBIC), National Poverty Eradication Center (NAPEB), Central Bank of Nigeria Entrepreneurship Development Centers, Youth Enterprise with Innovation in Nigeria (YouWIN) and many others (Ibitomi \& Adeleke, 2020).

\section{Concept of Unemployment}

The international labour organization (ILO) defines the unemployed as the number of all economically active population who are without work but are available for and are seeking work, including those who have lost their jobs and those who have voluntarily left work (World Bank, 2008). According to the International Labour Organization (2007), unemployed workers are those who are currently not working but are willing and able to work for pay, currently available to work and have actively searched for work.

Also, in the opinion of Fajana (2000), unemployment refers to a situation where people who are willing and capable of working are unable to find suitable paid employment. It is one of the macro-economic problems which every responsible government is expected to monitor and regulate. In the same vein, According to Olaaele, Akeke, and Oladunjoye (2011)), unemployment is "a situation in which persons capable and willing to work are unable to find suitable paid employment".. Hornby (2010) defines unemployment as "the facts of a number of people not having a job; the number of people without a job; the state of not having a job". Thus, unemployment is a situation where the teaming population who are mentally and physically capable to work are not able to get a commensurable job. 


\section{Concept of Empowerment}

Empowerment has been defined as an intentional ongoing process centered in the local community, involving mutual respect, critical reflection, caring, and group participation, through which people lacking an equal share of valued resources gain greater access to and control over those resources; or a process by which people gain control over their lives, democratic participation in the life of their community, and a critical understanding of their environment (Perkins \& Zimmerman, 1995; Islam et al., 2018).

The common elements in those definitions are that empowerment (a) is a process, (b) occurs in communities (and, I would add, in organizations), (c) involves active participation, critical reflection, awareness and understanding (i.e., consciousness raising about the influence of powerful political and economic structures and interests), and (d) involves access to and control over important decisions and resources. The only difference is that the second definition does not mention creating a climate of mutual respect and caring, which may be especially important for political and civic leaders to include in their understanding and practice of empowerment (Gutierrez \& Ortega, 1991). However, empowerment is the process through which the less privileges are resuscitated for an improved standard of living and socio wellbeing.

\section{Concept of Technical Skills}

Skills are at the core of improving employment outcomes and increasing productivity and growth in Nigeria, as in many developing countries. Education and training systems lack quality and labor market relevance, leaving workers ill-prepared for the labor market. Many workers lack the right skills to meet the requirements in available job openings or have limited opportunities to access high-quality pre-employment or skills upgrading training programs that promote higher-productivity jobs.

Technical skills are the combinations of cognitive and non-cognitive skills frequently used to accomplish specific tasks at work. Cognitive skills capture the individual's 'ability to understand complex ideas, to adapt effectively to the environment, to learn from experience, to engage in various forms of reasoning, and to overcome obstacles by taking thought' (American Psychological Association, 1995). The most common examples relate to literacy, numeracy, and the ability to solve abstract problems.

Non-cognitive skills relate to multiple characteristics across various domains (including social, emotional, personality, behaviors, and attitudes) that are not included under cognitive skills.

Examples of these skills translate into the individual's work habits (including the level of effort, discipline, or determination); behavioral traits (including self-confidence, sociability, or emotional stability); and physical characteristics (including strength and endurance).

\section{Poverty Concept}

Poverty is very difficult to define as a result of different ideologies of various disciplines. The wide spread definition since World War 11 define poverty in monetary terms, using level of income and consumption to measure poverty (Dollar \& kraay, 2000). However, this economic definition has been complemented in recent years by other approaches including the basic need approach, capabilities approach and the human development approach (UNDP, 2006). Their acceptance is reflected in the wide spread use of the United Nations Development Programme's (UNDP) Human development Index (HDI) which is composite measure of three dimensions of human development: 
i. Life expectancy,

ii. Educational attainment and

iii. Standard of living, measured by income in terms of its purchasing power parity, (UNDP, 2006).

Poverty is also defined by a sense of helplessness, dependency and lack of opportunities, self-confidence and self-respect on the part of the poor. Indeed, the poor themselves see powerlessness and noiselessness as key aspect of their poverty (Mclamed, Hartwig \& Grant, 2011)

For the purpose of this study, poverty is a state of not having a job, economic dependent at adult age, inability to provide the basic need for self and family, over indebtedness and above all, lack of quality education.

\section{Theoretical Framework}

Basically, the concept of entrepreneurship is rooted in cognitive or trait theory, and microeconomic theory. Cognitive theory focuses on identifying needs and taking risks to combine resources in order to meet the needs. In other words, it describes how individuals with certain traits are able to identify gaps in the society and fill the gaps. Since entrepreneurs are known to possess some characteristic traits that make them high achievers and unique, it also describes how some unique traits enable entrepreneurs to conduct business activities profitably, withstand pressure, overcome challenges, break barriers, and produce goods and services that better the lives of citizens ((Cleland Hoy \& Boulton, 1984).

Microeconomic theory, on the other hand, focuses in details on resources allocation and utilization among individual components of the economy. It describes how resources are efficiently allocated, and utilized in order to make profit and avoid wastage. For instance, the decisions of entrepreneurs about what to produce, how to produce, where to produce, and what prices to charge, are contained in microeconomic theory, which can be linked to the resource and management factors needed for business growth and development. These two theories, combined together, describe the fundamental activities carried out by individuals who efficiently allocate and utilise available resources, and take risks in order to create value and develop the society. McClelland's belief is that achievement motivated people are generally those who make things happen and get results and this extends to getting results through the organization of other people and resources. The implication is that doing things better when the requisite skills must have been acquired, will naturally open up ideas and job opportunities through the expansion of business ventures to eventually absorb the army of unemployed youth in Nigeria.

\section{Empirical Review}

Prior studies on entrepreneurial development among scholars presented varied perspectives and findings. Empirical: Okafor (2019) carried out a study on reducing unemployment rate in Nigeria through entrepreneurship development. The study which was designed as a descriptive survey using item structured instrument to elicit information from the respondents, in other to evaluated the role of government in trying to make the process an effective means of tackling the menace of unemployment. The study revealed that tertiary institutions and other entrepreneurial training centers can be reformed to make them responsive to the needs of the trainees.

Ekong and Ekong (2016) carried out a study on skills acquisition and unemployment reduction in Nigeria, using the National Directorate of Employment as the study area. The study period was 1987-2012. Designed as a descriptive survey, the study found that positive 
link exist between skills acquisition by NDE and unemployment reduction in Akwa Ibom State. The study was carried out in Akwa Ibom State while this is carried out in Osun State. The study also considers only National Directorate of Employment whereas, this study considers both NDE and Npower programme

Osoguwa and Dim (2016) carried out a study on entrepreneurial development and unemployment reduction in Nigeria. The study was meant to determine the relationship between Entrepreneurship training; trait; empowerment; entrepreneurship challenges unemployment in the selected LGAs. Data was collected using questionnaire from an infinite population through a convenience sampling technique. The study found that the variables in Ho1, Ho2 and Ho3 were significantly and positively related and Ho4 was also significant. The study was carried out in Anambra State while this study is done in Osun State. The study also considered entrepreneurial development, meanwhile, this work is carried out on entrepreneurial development programmes

Eme (2019) carried out research on unemployment rate in Nigeria: Agenda for Government. He found out that in the last couple of years, Nigeria's economy is one of the fastest-growing in the world while its people are the most impoverished in real terms. Experts fear that Africa, particularly Nigeria's share of the global scourge might increase disproportionately, with attendant unsavoury consequences unless the country immediately adopts pro-active and holistic approach to halt the rising youth unemployment.

Okoye, Iloanya and Udunze (2018) carried out research on the extent to which entrepreneurship in Nigeria has helped to reduce youth unemployment. The study revealed that government policies and initiative has affected the "transformation question". This is due to the increase of corruption, inadequate and maladministration. They concludes that entrepreneurship country is an engine for job creation, innovation and diversity and that Nigeria's entrepreneurs have a long way to go before they can effectively drive changes in the economy. They recommend that government should genuinely recognize the essence of entrepreneurship to economic development by providing the enabling environment for the youth to be gainful employed for economic development. Aribaba (2013) carried out an empirical research on of the effect of participation in entrepreneurial development programmes on enterprise performance in Nigeria. He evaluated the relationship between participation in entrepreneurial development programmes and the enterprise performance in Nigeria. He found out that in any giving economy, participation in entrepreneurial development programmes will enable people to do something that will better their lives and improve the economy of the country at large It was clear from his observation that job creation or employment opportunity in an economy can be traceable to entrepreneurship training and development.

Akanwa and Akpanabia (2012) examined the need for promoting employment in Nigeria through the development of entrepreneurship. The work relies mostly on secondary data from scholars/ authors in the field. They concluded that, government and its agencies should deliberately encourage entrepreneurial culture and skill in Nigeria in order to attack and eventually reduce the high level of unemployment situation in the country so that the nation will boost its economic development. The researcher feels that the work relies mostly on secondary data.

\section{Methodology}

The study adopted survey research design in other to investigate the government entrepreneurship development programmes on unemployment reduction in Osun State. Nigerian Governments have put in place several strategies and programmes and also 
established many agencies across the 36 states and federal capital, among which the National Directorate of Employment (NDE) and N-Power programmes are selected because of their unique aimed of assisting the citizens of the state to acquire employable skills to become economically stable. The population of both NDE and N-power programmes from inception, comprises of twenty-five thousand and seventeen thousand $(25,000 \& 17,000)$ for both NDE and N-Power respectively. The sample of four hundred (400) and two hundred and fifty (250) from both NDE and N power respectively, making a total of six hundred and fifty (650), was drawn from the population across the three-senatorial district, using Taro Yamane (1967) formula for estimating sample. A total of 650 questionnaires were administered out of which six hundred and thirty-two (632) were filed and returned appropriately which represent $97 \%$.

Primary source of data collection was used with the questionnaire as an instrument. The questionnaire was divided into two sections: section A on demographic factor while section B captures questions relating to the subject matter of the research. Using a Likert scale of 5 points, the degree of agreement of the respondents to each of the items in the questionnaire is measured in terms of Strongly Agreed (SA), Agreed (A), Undecided (U), Disagreed (D), and Strongly Disagreed (SD) with the value of 5, 4, 3, 2, and 1 respectively. The researcher used content and face validity to measure the research instrument. The reliability coefficient is obtained using the Cronbach's Alpha reliability test. This was preferred because it captures full scale reliability rather than split half reliability and produced a value of 0.76 . This implies that the instrument of data collection was reliable. The data obtained through questionnaire was analysed and interpreted. The researcher used simple percentage method to analyse and interpret the data on the questionnaire and used multiple regression statistical analysis to test the two null hypotheses postulated at 0.05 level of significance. These analyses were performed with the aid of statistical package for social science (SPSS version 20).

\section{Data Analysis and Discussion}

Table 1: Responses Rate

\begin{tabular}{|c|c|c|}
\hline Response rate & Frequency & Percentage (\%) \\
\hline Returned & 632 & 97.23 \\
\hline Unreturned & 18 & 2.77 \\
\hline Total & 650 & $100 \%$ \\
\hline
\end{tabular}

Test of Research Hypothesis 1

Ho1: N-power does not significantly address poverty reduction.

Table 2: Model Summary

\begin{tabular}{|c|c|c|c|c|}
\hline $\begin{array}{c}\text { Mode } \\
1\end{array}$ & $\mathrm{R}$ & $\mathrm{R}$ Square & $\begin{array}{c}\text { Adjusted R } \\
\text { Square }\end{array}$ & Std. Error of the Estimate \\
\hline 1 & $.782^{\mathrm{a}}$ & .687 & .682 & 1.14393 \\
\hline & & & & \\
\hline
\end{tabular}

Table 2 shows that $\mathrm{R}$-Square $\left(\mathrm{R}^{2}\right)$ value is 0.687 . This implies that $68.7 \%$ of the variations in the dependent variable (Entrepreneurial skills) were explained by the constant variables 
(technical skills, and non-cognitive or socio-behavioral skills), while the remaining $31.3 \%$ is due to other variables not appear in the model.

Table 3: ANOVA $^{\mathrm{a}}$

\begin{tabular}{|c|c|c|c|c|c|c|}
\hline \multicolumn{2}{|c|}{ Model } & $\begin{array}{l}\text { Sum of } \\
\text { Squares }\end{array}$ & Df & $\begin{array}{l}\text { Mean } \\
\text { Square }\end{array}$ & $\mathrm{F}$ & Sig. \\
\hline \multirow{3}{*}{1} & Regression & 1798.430 & 4 & 449.608 & 112.402 & $.000^{b}$ \\
\hline & Residual & 425.220 & 628 & 2.994 & & \\
\hline & Total & 2250.650 & 632 & & & \\
\hline
\end{tabular}

a. Dependent variable: poverty reduction

a predator: (constant), cognitive skills, technical skills, and non-cognitive or sociobehavioral skills.

The $\mathrm{p}$ value of $0.000<0.05$ ( $\mathrm{sig}$ ) in the ANOVA table 2 indicates that the variables under consideration are jointly significant. The implication of this test was that a single variable such as technical skills is an element of poverty reduction, may not be significant to influence beneficiaries, but when combined with other such as non-cognitive or socio-behavioral skills, they can jointly influence the quality of the beneficiaries.

Table 4: Coefficients ${ }^{\mathrm{a}}$

\begin{tabular}{|c|c|c|c|c|c|c|}
\hline \multirow{2}{*}{\multicolumn{2}{|c|}{ Model }} & \multicolumn{2}{|c|}{ Unstandardized Coefficients } & \multirow{2}{*}{$\begin{array}{c}\begin{array}{c}\text { Standardized } \\
\text { Coefficients }\end{array} \\
\text { Beta }\end{array}$} & \multirow[t]{2}{*}{$\mathrm{T}$} & \multirow[t]{2}{*}{ Sig. } \\
\hline & & $\mathrm{B}$ & Std. Error & & & \\
\hline \multirow{3}{*}{1} & (CONSTANT) & 2.597 & .390 & & 9.887 & .000 \\
\hline & Technical Skills & .213 & .054 & .375 & 2.898 & .003 \\
\hline & non-cognitive skills & .316 & .160 & .456 & 3.678 & .000 \\
\hline
\end{tabular}

a. Dependent variable: poverty reduction

Table 4 estimated regression equation indicate that poverty level will reduced by 0.213 and 0.316 when there is an increase in technical skills, and non-cognitive or socio-behavioral skills by one unit, while other variable remain constant. However, the model coefficient (that is, the intercept and the slope) shows that "technical skills" $(B=0.375 \mathrm{p}$-value $=0$. 003 ) is statistically significant at 5\% level. This implies that technical skills bring about $37.5 \%$ reduction on youth poverty rate. The result also shows that "non-cognitive or sociobehavioral" $(\mathrm{B}=0.456, \mathrm{p}$-value $=0.000)$ is statistically significant at $5 \%$ level. This implies that intellectual commitment bring about $45.6 \%$ improvement on poverty reduction.

This implies that participant perform better when they are given technical skills irrespective of programmes and units which therefore have significant impact on the effectiveness of entrepreneurship development programmes improvement to tackle unemployment. Also, non-cognitive or socio-behavioral skills given to the beneficiaries of $\mathrm{N}$-power in various units lead to an improvement in the efficiency of the programmes. This result is in line with the study of Aribaba, (2013) which affirmed that of productive skills and investments knowledge reduce poverty, which improve efficiency of the programmes and at the same time reduce poverty level in the state.

Test of Research Hypothesis 11

$\mathrm{Ho}_{2}$ : NDE programme does not have significant impact on youth empowerment 
Table 5: Model Summary

\begin{tabular}{|l|r|r|r|r|}
\hline $\begin{array}{l}\text { Mode } \\
1\end{array}$ & \multicolumn{1}{c|}{$\mathrm{R}$} & R Square & Adjusted R Square & Std. Error of the Estimate \\
\hline 1 & $.656^{\mathrm{a}}$ & .598 & .587 & 0.72193 \\
\hline
\end{tabular}

a. predator: (constant), Government commitment and beneficiaries' commitment/interest

The model summary as indicated in table 5 shows that $\mathrm{R}$-Square $\left(\mathrm{R}^{2}\right)$ value is 0.598 . This implies that $59.8 \%$ of the variations in the dependent variable (youth empowerment) were explained by the constant variables (Government commitment, beneficiaries interest), while the remaining $40.2 \%$ is due to other variables not included in the model.

Table 6: ANOVA

\begin{tabular}{|c|c|c|c|c|c|c|}
\hline \multicolumn{2}{|c|}{ Model } & Sum of Squares & Df & Mean Square & $\mathrm{F}$ & Sig. \\
\hline \multirow{3}{*}{1} & Regression & 59.873 & 2 & 29.937 & 24.614 & $.000^{\mathrm{b}}$ \\
\hline & Residual & 272.415 & 165 & 1.651 & & \\
\hline & Total & 332.288 & 167 & & & \\
\hline
\end{tabular}

a. Dependent variable: youth empowerment

b. predator: (constant), Government commitment, Beneficiaries interest

The ANOVA table 6 which texted the goodness of the variables shows that $p$-value $=0.000$ $<0.05$ (sig). This indicates that the variables under consideration are jointly significant. The implication of this test was that a single variable, government commitment as an element of NDE programme may not be significant to empower the youth, but when combined with other such as beneficiaries commitment/interest, they can jointly influence the creation of the empowered and confident youth.

Table 7: Coefficients ${ }^{\mathrm{a}}$

\begin{tabular}{|c|c|c|c|c|c|c|}
\hline \multirow{2}{*}{\multicolumn{2}{|c|}{ Model }} & \multicolumn{2}{|c|}{$\begin{array}{c}\text { Unstandardized } \\
\text { Coefficients }\end{array}$} & $\begin{array}{l}\text { Standardized } \\
\text { Coefficients }\end{array}$ & \multirow[t]{2}{*}{$\mathrm{T}$} & \multirow[t]{2}{*}{ Sig. } \\
\hline & & $\mathrm{B}$ & Std. Error & Beta & & \\
\hline \multirow{3}{*}{1} & (Constant) & 1.636 & .179 & & 8.215 & .000 \\
\hline & $\begin{array}{l}\text { Government } \\
\text { commitment }\end{array}$ & .551 & .075 & .543 & 7.735 & .000 \\
\hline & $\begin{array}{l}\text { Beneficiaries } \\
\text { commitment }\end{array}$ & .434 & .070 & .481 & 8.728 & .001 \\
\hline
\end{tabular}

a. Dependent variable: youth empowerment

As shown in table 7, productivity is equal to 1.636 when all other things are held constant. The number of empowered youth will increase by 0.551 and 0.434 when there is an increase in government and beneficiaries' commitment by one unit, while other variables remain constant. However, the model coefficient shows that "government" $(\mathrm{B}=0.543 \mathrm{p}$-value $=$ 0.000 ) is statistically significant at $5 \%$ level. This implies that government commitment brings about $54.3 \%$ improvement on the kind of empowerment giving to the youth. The result also shows that "beneficiaries' commitment" $(\mathrm{B}=0.481$, $\mathrm{p}$-value $=0.001)$ is statistically significant at 5\% level. This implies that beneficiaries' commitment brings about $48.1 \%$ improvement on quality of empowerment received by the youth.

This indicates that a higher than normal level of the commitment on the part of both the government and the beneficiaries has greatly affected the effectiveness and efficiency of 
entrepreneurship development programmes in terms of quality entrepreneurs. A combination of government and beneficiaries' commitment can positively reduce unemployment. Audretch et al., (2017), which support this study emphasized government commitment to empower the youth.

\section{Conclusion and Recommendations}

It was concluded that, it is inevitable to embark on the study of this kind because the economy of Nigeria as the most populous country in Africa, and many country of the world are battling with a serious unemployment among the youth, which may not be ameliorated without paying special attention to entrepreneurship development programmes. Unemployment in the country is reduced (with the number of the beneficiaries) as beneficiaries now have ability to understand complex ideas, analyse and adapt effectively to the environment and create more job when they make use of the skills acquired. Evidence from the study also revealed that beneficiaries are to a certain extent socially and emotionally stable and now have more confidence to create more job which will actually reduce the level of unemployment, particularly in the state of Osun. A combination of cognitive skills, and non-cognitive or socio-behavioral skills acquired in the cause of the programme will help them to create job for others which therefore reduce unemployment. Based on the findings of the study, we concluded that NDE and N-power reduced unemployment rate in Nigeria though at a very slow space.

It is therefore recommended that to generate employment or reduce poverty, government should be highly committed to the programmes through consistent policies and strategy for monitoring the responsible agencies and provision of adequate resources needed to equip the beneficiaries who in turn should be burning with ambition for growth, desire for achievement and potential for economic autonomy. This is because, the combine effort of government and beneficiaries is important to solve the developmental problems of unemployment in the state and the country at large, which is the major aim of establishing the programme. It is also recommended that, in other to produce a typical entrepreneur that will not only be self-employed but employ more other unemployed youth, government should make it as a point of duty that beneficiaries are given (or equipped with) practical training and ensure they acquire necessary skills, both cognitive and non-cognitive skill during and after the programme. This is because, when the right practical skill acquired by the beneficiary is utilize, they create value for themselves sand employ more hands which therefore enhance the effectiveness of entrepreneurship programmes and reduce the rate of unemployment in the state and Nigeria at large.

\section{Limitation of the Study and Future Direction}

The study was attributed to limitation in terms of the distribution of the questionnaire, as many respondents feel reluctant in filling the questions though with series of enlighten on the need to fill the questionnaire many of the respondents carried out the task. The issue of finance was also bottleneck to this research work as we spent a lot to get the right information on this study, with the help of friends we were able to finance the study without any hitches. The selection of the sample size and sampling techniques was another serious limitation to this research work, with the help of our learned colleagues in the office, we are able to do the right thing that will give us the right sample size and techniques for the study.

Based on the limitation of this study, future research work should be directed to other states of the federation in Nigeria majorly on regional level since this study focused on state. More relevant topics on entrepreneurship should be used as research study in the future since 
the aim of government is to reduce unemployment level in the country though creation of more jobs through entrepreneurship.

\section{References}

Adejumo, G. (2001). Indigenous entrepreneurship development in Nigeria: Characteristics, problems and prospects. Advances in Management. Journal of Department of Business Administration, University of Ilorin, Nigeria, 2(1), 112-122.

Adelekan, S. A., \& Tijani, A. A. (2017). Effect of support for entrepreneurship development on economic growth and development in Nigeria. European Scientific Journal, ESJ, 13(13).

Agu, E. (2019). Government assisted programmes and unemployment reduction in developing economies; A study of Nigeria and Ghana. International Journals of Management economics and social sciences, 8(4), 280-298.

Akanwa, B., \& Agu, C.N. (2005). Entrepreneurship: Theory and Practice in Nigeria. 1st Edn. Resources Development Centre, Owerri.

Anyadike, N., Emeh, I.E.J. \& Ukah, F.O. (2012). Entrepreneurship development and employment generation in Nigeria: Problems and prospects. Universal Journal of Education and General Studies, 1 (4): 88-102.

Aribaba, F. O. (2013). The examination of the effect of participation in entrepreneurial development programmes on enterprise performance: A case of small-scale business in Nigeria, Mediterranean Journal of Social Science, 4(1), 237-242.

Audretch, D. B., Grilo, I., \& thurik, A. R. (2017). Explaining entrepreneurship and the role of policy: A framework in the handbook of research on entrepreneurship policy. Edward publishing, 1-17.

Baba, G.K. (2010). The challenges of entrepreneurship development in Nigeria and way forward. Journals of Business Organization Development. 5(1):54-64.

Cleland, J. W., Hoy, F., \& Boulton, W. R. (1984). Differentiating entrepreneurs from small business owners: A conceptualization. Academy of Management Review, 9(2), 354359.

DFID (2017). Job Creation and Youth: Empowerment in Nigeria, A Policy Development Facility Phase II (PDF II) of a Flexible, Rapid-Response Programme. https://www.dai.com/uploads/Job-Creation-and-Youth-Empower ment-inNigeria.pdf Retrieved, 28/03/2019

Ebiringa, O. T. (2013). Entrepreneurship development for sustainable economic transformation:

Ekong, U.M. \& Ekong, C.U. (2016). Skills acquisition and unemployment reduction in Nigeria: a study of National Directorate of Employment (NDE) in Akwa Ibom State. International Journal of Economics and Management Sciences, 5(4):2-10.

Eme, O.I. (2019). Unemployment rate in Nigeria: agenda for government. Academic Journal of Interdisciplinary Studies, 3:103-114.

Fajana, S. (2000). Functioning of the Nigerian Labour Market. Lagos: Labonfin and Company. Federal Office of Statistics Abuja.

Gartner, W. B. (1988). Who is an entrepreneur? is the wrong question. Entrepreneurship, Theory and Practice, 13(4), 47-68.

Gutierrez, L. M., \& Ortega, R. (1991). Developing methods to empower Latinos: The importance of groups. Social Work with Groups, 14(2), 23-43. 
Haque, A., Anwar, N., Yasmin, F., \& Islam, M. A. (2018). An exploratory study toward understanding social entrepreneurial intention. Journal of International Business and Management, 1(3), 1-16.

Ibitomi, T. \& Adeleke, O.J. (2020). Analyses of entrepreneurship education on entrepreneurial intention among undergraduates students in Nigeria. Journal of Business and Innovation Research, 8(8), 1-8

International Labour Organization (2012). Report 1, General Report, 17th International Conference of Labour Statisticians, Geneva, 24 November - 3 December 2003, 100 p.

Islam, M. A., Jantan, A. H., Hunt, A., Rahman, M. F., \& Abdullah, M. M. (2019). Exploration of barriers faced by female graduate entrepreneurs in Bangladesh. Entrepreneurship and Sustainability Issues, 7(2), 1000-1014.

Islam, M. A., Jantan, A. H., Aldaihani, F., Rahman, M. A., Khan, A. M., Shahin, S., \& Alam, M. N. (2018). Impact of empowerment, flexibility and trust on women's access to senior positions in RMG industry of Bangladesh. International Journal of Entrepreneurship, 22(3), 1-11.

Iwayemi, A. (2013). Youth unemployment in Nigeria - challenges and way forward. Paper presented at the World Bank Regional workshop on youth employment. Abuja.

Mathew, O.J., \& Victor, A.A. (2018). Reducing unemployment in Nigeria; An evaluation of the entrepreneurship programme in Ondo State. Journal for Studies in Management and Planning, 4(1), 26-38.

Nwachukwu, A. C. (2012). The role of entrepreneurship in economic development: The Nigerian Perspective. European Journal of Business and Management, 8(4), 95105

Okafor, E. E. (2011). Youth unemployment and implication for stability of democracy in Nigeria. Paper presented in the Department of sociology, University of Ibadan, Ibadan Nigeria.

Okafor C. A. (2019). Reducing unemployment rate in Nigeria through entrepreneurship development. European Journal of Research and Reflection in Management Sciences, 7(1), 2056-5992

Perkins, D.D., \& Zimmerman, M.A. (1995). Empowerment theory, research, and application. American. Journal of Community Psychology, 23, 569-579.

Salami C.G.E. (2013). Youth unemployment in Nigeria: A time for creative intervention. International Journal of Business and Marketing Management, 1(2); pp. 18-26,

Sule, M. (2014). The role of entrepreneurship education on job creation among youths in Nigeria. International journal of social and humanistic sciences, 4, 87-96.

United Nation Development Programme (2006). World Development report. Publication of the International Labour Organization. Retrieved from www.nationmaster.com

Wernerheim, C. M. (2010). The tendency of advanced services to co-locate and the implications for regional government policy. The Service Industries Journal, 30(5), 731-748.

World Bank (2009). World Development Report 2009: Reshaping economic geography Washington, DC: World Bank.

YOUWIN (2013). Youth enterprise with innovation in Nigeria, Journal of Sustainable Development in Africa, 15(5), 49-59.

This work is licensed under a Creative Commons I Attribution-NonCommercial 3.0 Unported License. 